\title{
Plant Tissue Culture Research and Development in Ethiopia: A Case Study on Current Status, Opportunities, and Challenges
}

\author{
Yemisrach Melkie Abebaw (D), ${ }^{1}$ Dagmawit Chombe Tobiaw, ${ }^{1}$ Birhan Addisie Abate, ${ }^{1}$ \\ Beza Kinfe Eshete, ${ }^{1}$ Sydney K. Seymour, ${ }^{2}$ and Kassahun Tesfaye ${ }^{1}$ \\ ${ }^{1}$ Ethiopian Biotechnology Institute, Addis Ababa, Ethiopia \\ ${ }^{2}$ SEYCONTECH, Mocksville, NC, USA \\ Correspondence should be addressed to Yemisrach Melkie Abebaw; yemisrach.melkie@gmail.com
}

Received 25 March 2021; Accepted 27 July 2021; Published 4 August 2021

Academic Editor: Othmane Merah

Copyright (c) 2021 Yemisrach Melkie Abebaw et al. This is an open access article distributed under the Creative Commons Attribution License, which permits unrestricted use, distribution, and reproduction in any medium, provided the original work is properly cited.

\begin{abstract}
Plant tissue culture (PTC) is one of the well-adapted and practiced biotechnology tools in Ethiopia. After the initial success of tissue culture at the Ethiopian Institute of Agriculture Research and Addis Ababa University, the technology spread its roots to most of the research institutes and universities across the country. Consequently, the technology continues to extend at the commercial level. However, there is a lack of information at the national level on the capacity of national institutes in terms of available infrastructure and skilled human power, the potential of the laboratories for tissue culture-related activities, and existing challenges that hinder tissue culture research and development. This study aimed to assess the status of tissue culture research and development in Ethiopia and identify gaps that hinder its application in various economic sectors. The primary data were collected from 19 tissue culture laboratories across the country using questionnaires and physical observation. Accordingly, the results of the study revealed that Jimma Agricultural Research Center from the federal research institute and Amhara Regional Agriculture Research Institute, Bahir Dar Laboratory, from the regional research institute are relatively well equipped with facilities and equipment for tissue culture R\&D activities. Among the commercial laboratories, Tigray Biotechnology Center is well equipped and has the highest production capacity with 40 million seedlings per year. Besides, the assessment revealed that a total of 54 plant species have been under in vitro protocol optimization and development process across all PTC laboratories. Nevertheless, tissue culture application in public and private sectors in Ethiopia is limited by several technical, administrative, and financial constraints. Therefore, to exploit the maximum benefit of PTC technology in the existing facilities, further intervention is critical in solving the identified challenges.
\end{abstract}

\section{Introduction}

Plant tissue culture (PTC) techniques are the most frequently used biotechnology tools ranging from basic to applied investigation purposes in plant sciences. The history of PTC research dates back to 1902, when Haberlandt cultured tissue from a Tradescantia plant species [1]. Since then, PTC has significantly impacted the current agriculture system worldwide and every year, hundreds of results and reports regarding the application of tissue culture techniques, applied to breeding programs, genetic and biodiversity conservation, and biopharmaceutical production are documented. Chemical and hormonal control of regeneration [2], basic and applied aspects of organogenesis and somatic embryogenesis [3], micropropagation and production of virus-free plants [4], haploid plants [5], production of secondary metabolites [6], and large-scale cell culture in bioreactors [7] are few landmarks and notable discoveries in PTC research.

The application of tissue culture technology as a central tool or as an adjunct to other methods, including recombinant DNA techniques, is at the vanguard in plant modification and improvement [8]. Biotechnology tools like genetic transformation and gene editing rely on the technical aspects of PTC. In the development of Genetically Modified (GM) and gene-edited crops, tissue culture is the primary 
tool to transfer target genes into host plants and regenerate the transgenic plants [9]. The selection of transformed or gene-edited plantlets and to multiply the final genetically modified or gene-edited genotypes is based on PTC techniques [10]. Furthermore, PTC is also widely used for the multiplication of disease-free plants [11] and the conservation of endangered plant species both on a commercial scale and on a small scale level. Besides, PTC was used to improve the production of pharmaceutically important secondary metabolites in medicinal plants [12]. Despite the huge potential of PTC in agriculture, its use and application in developing countries like Ethiopia are in its infancy.

In Ethiopia, the first PTC research laboratory was established at Ethiopian Agricultural Research Institute, Holeta Agricultural Research Center, and at Addis Ababa University, Department of Biology in 2000 [13]. Since then, there has been an exponential expansion in Ethiopian tissue culture research laboratories at regional agricultural research institutes and higher learning institutions [13]. Commercial tissue culture was started in Ethiopia in 2006 when Tigray Biotechnology Center (TBC), PLC was established as the first private PTC laboratory. Then the remarkable development and startup of commercial laboratories followed in different parts of the country, such as Bahir Dar TC Enterprise, Waginos Biotech, and Dessie Tissue Culture Laboratory. However, there is a lack of information at the national level on the capacity of institutions in terms of available infrastructure and skilled human power, the potential of the laboratories for tissue culture related activities, and existing challenges that hinder tissue culture research and development. Therefore, this study was conducted to assess the current status, potential, and associated challenges of PTC research and development in Ethiopia.

\section{Approach and Methodology}

2.1. Institutions and Laboratories. The assessment targeted public and private institutes that have been actively involved in PTC R\&D. It relied on collecting information from currently active laboratories in PTC research and development across the country. In total, nineteen (19) PTC laboratories were assessed. These laboratories are all located in five (5) regions of Ethiopia: Addis Ababa City, Amhara Regional State, Oromia Region State, Southern Nations, Nationalities and People (SNNP) Regional State, and Tigray Regional State. The specific location of each laboratory evaluated in the assessment is shown in Figure 1. The institutions and laboratories assessed in this study are listed as follows:

(i) Ethiopian Agricultural Research Institute (EARI): National Agricultural Biotechnology Research Center (NABRC, Holetta); Jimma Agricultural Research Center; Melkassa Agricultural Research Center; and Debre Zeit Agricultural Research Center.

(ii) Regional Agricultural Research Institutes (RARIs): Amhara Regional Agriculture Research Institute (ARARI)-Bahir Dar TC Laboratory, Southern
Nations, Nationalities and People Region Agricultural Research Institute (SRAI)-Areka Agricultural Research Center, Oromia Regional Agriculture Research Institute (ORARI)-Adami Tulu Agricultural Research Center; and Tigray Regional Agriculture Researcher Institute (TARI)-Mekelle Agricultural Research Center.

(iii) Higher learning institutions: Addis Ababa University, Gondar University, Hawassa University, Haramaya University, Jimma University College of Agriculture and Veterinary Medicine (JUCAVM), Jimma University Biology Department, and Wolkite University.

(iv) Private/commercial: Tigray Biotechnology Center (TBC), Dessie Tissue Culture Center, Bahir Dar Tissue Culture Enterprise, and Waginose Biotech Private Limited Company (PLC).

2.2. Data Collection. The data were collected from first-hand information across all the 19 laboratories using a questionnaire. The questionnaire encompassed different issues related to the PTC process, including infrastructure and laboratory facility, human resources, available technologies, opportunities, and challenges (Supplementary file 1). The questionnaires were distributed to the respective institutes and filled by the person who was in charge of the PTC laboratory. The assessment was conducted from June to July 2019.

2.3. Data Analysis. In the present assessment, both quantitative and qualitative data analysis techniques were employed. The data gathered through the questionnaire from different institutes were analyzed and presented using means, percentages, graphs, charts, and tables. Microsoft Excel was employed to analyze the data.

\section{Results and Discussion}

\subsection{Current Status and Available Technology}

3.1.1. Status of Infrastructure and Equipment. In Ethiopia, tissue culture research and development is implemented through government institutes and private companies. Currently, a total of fifteen (15) governmental and four (4) commercial plant tissue culture laboratories are involved in $\mathrm{R} \& \mathrm{D}$ across the country. Consequently, the current infrastructure, capacity, and facility of all these laboratories have been assessed during the visit.

Any laboratory, which actively practices the PTC technics, must contain basic facilities, which include the following four laboratory compartments: (a) general washing area; (b) media preparation, sterilization, and storage area; (c) aseptic transfer area; (d) environmentally controlled incubators or culture rooms [14]. Almost all surveyed laboratories have a cleaning and media preparation room. However, very few laboratories (10\%) lack a specific area for cleaning and mixing the washing area with other compartments. In addition, some of the laboratories (31.5\%) do 


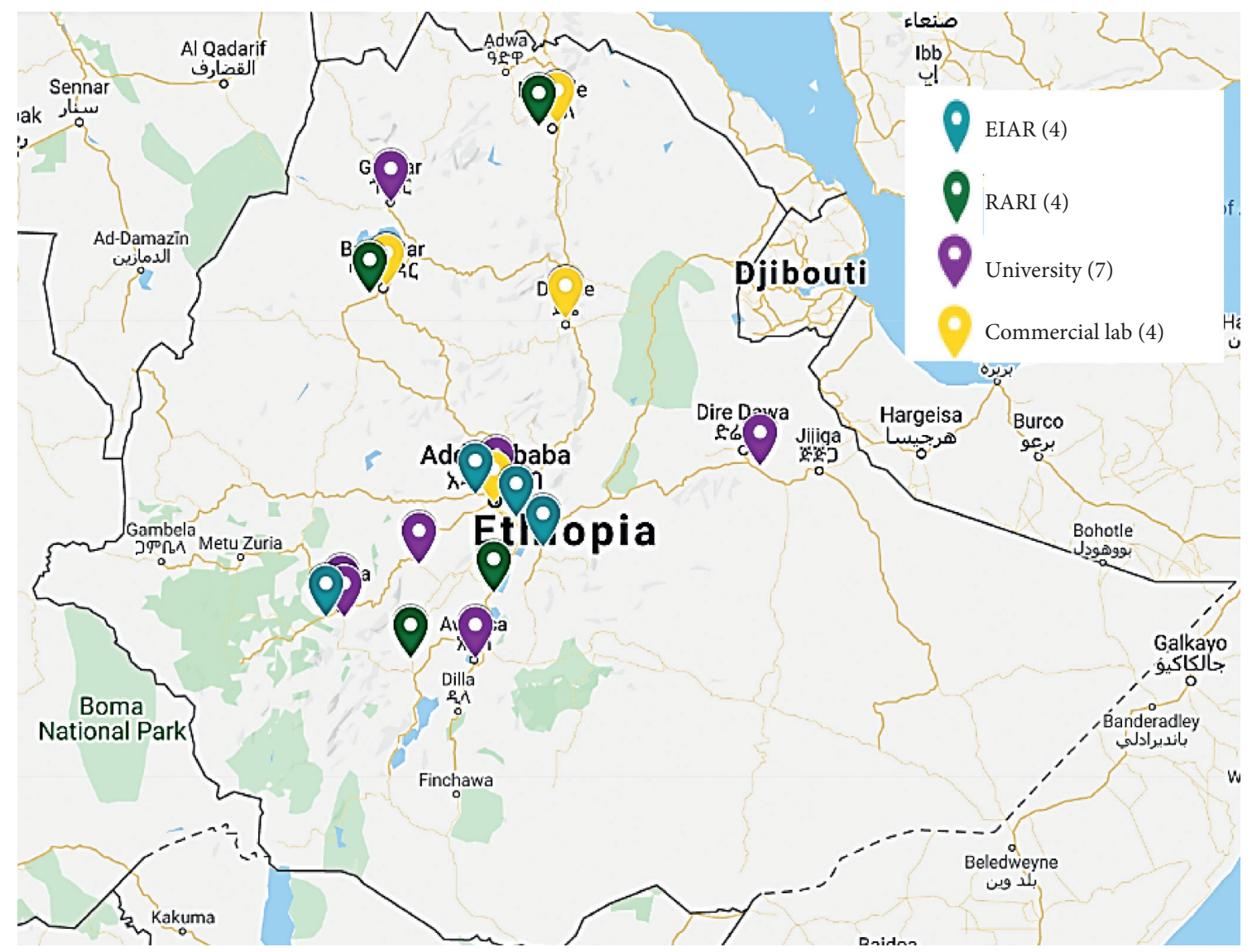

Figure 1: Location of plant tissue culture laboratories involved in the assessment.

not have a media storage room. Instead, they store media in any available space at room temperature without the appropriate storage condition. About $42 \%$ of the laboratories lack a dark room; as a substitute, they use black polythene sheeting to cover samples that are required to be in a dark room. A large majority of laboratories (93\%) have a room dedicated to the culture transfer and growth room. Among the evaluated laboratories, $15 \%$ have small inappropriately designed areas and lack basic equipment in the transfer and growth rooms (Supplementary file 2). The basic set-up of the laboratory is an important factor for the final success of tissue culture experiments. Thus, laboratories that lack the basic components, such as a storage room and/or a dark room, should be designed and refurbished to improve the operational level of the facility according to established standards and best practices for PTC work.

(1) Public Research Institutions. The current status of infrastructure and equipment resources in government research institutes is presented in Table 1. Jimma Agricultural Research Center from the federal research institute and ARARI, Bahir Dar TC Laboratory from regional research institute are relatively well equipped with facilities and equipment for tissue culture R\&D activities with appropriate workflow. The PTC techniques for most plant species often require similar basic laboratory equipment [14]. Any laboratory in which tissue culture techniques are performed, regardless of the specific purpose, must contain a number of basic laboratory equipment. These usually include the equipment listed in Table 1. A minimum number/volume of each item is needed for a successful PTC experiment [15]. However, the assessment revealed that most of these items/ equipment were absent from all the laboratories, besides some of the available equipment was reported to be nonfunctional (Table 1). For instance, in most research laboratories surveyed, basic infrastructure and facilities such as water purification apparatus, distillers, microscopes, and autoclaves were either not available or not fully functioning. These observations indicate that the available equipment in the assessed institutes is not adequate to conduct reasonable and useful R\&D in tissue culture with high standards for quality and reproducible results. Therefore, to increase the contribution of quality and quantity of PTC research in government-owned laboratories to economic development, further intervention on the upgrading of infrastructure and facilities is critical.

(2) Higher Learning Institution. The assessment results show that among the higher learning institutions, Addis Ababa University was the first university in Ethiopia to start the implementation of tissue culture techniques for the micropropagation of indigenous tree plants. Moreover, the survey revealed that Wolkite University has a higher number of PTC laboratory equipment as compared to other higher education 
TABLE 1: List of basic equipment available in plant tissue culture laboratories at Ethiopian agricultural research institutes.

\begin{tabular}{|c|c|c|c|c|c|c|c|c|}
\hline \multirow[t]{2}{*}{ Equipment } & \multicolumn{8}{|c|}{ Number of equipment in the research institute } \\
\hline & NABC & MARC & JARC & DZAR & ARARI & ORARI & SARI & TARI \\
\hline \multicolumn{9}{|c|}{ Media preparation and autoclaving unit } \\
\hline Autoclaves & $2+1^{*}$ & $3+1^{*}$ & $2+8^{*}$ & $1+1^{*}$ & $2+2^{*}$ & $1+1^{*}$ & $1+1^{*}$ & $4^{*}$ \\
\hline Precision balances & $2+1^{*}$ & 2 & 3 & 2 & $1+2^{*}$ & $2+1^{*}$ & $1+1^{*}$ & 4 \\
\hline PH meter & $1+4^{*}$ & $2+1^{*}$ & $2+4^{*}$ & 2 & $2+3^{*}$ & $2+2^{*}$ & $1+1^{*}$ & 2 \\
\hline Water purification apparatus & 1 & - & - & 1 & - & - & 1 & 1 \\
\hline Refrigerated centrifuge & - & - & - & 1 & - & - & - & - \\
\hline Deep freezers $\left(-20^{\circ} \mathrm{C}\right)$ & 1 & $1+1^{*}$ & - & 1 & 1 & - & - & 2 \\
\hline Fridge/freezer comb & $2+1^{*}$ & - & 6 & 2 & 2 & - & 2 & 1 \\
\hline Hot plate with stirrer & 3 & 2 & 2 & 3 & 2 & 3 & 2 & 2 \\
\hline Micropipettes (sets) & & 1 & 3 & 5 & 1 & 2 & 1 & \\
\hline Microwave oven & 1 & - & 1 & 1 & 2 & - & 1 & \\
\hline Rotary shaker & $1+1^{*}$ & - & 4 & 1 & - & - & 1 & 1 \\
\hline Water distiller (single) & - & $2+1^{*}$ & $2+8^{*}$ & 2 & $1+1^{*}$ & $1+2^{*}$ & 1 & 2 \\
\hline Water distiller (double) & 1 & - & - & - & - & - & - & - \\
\hline Deep freezer $\left(-80^{\circ} \mathrm{C}\right)$ & - & - & - & 1 & - & - & - & - \\
\hline \multicolumn{9}{|c|}{ Working area and growth room unit } \\
\hline Laminar flow hood & $3+2^{*}$ & $5+2^{*}$ & 6 & 3 & 3 & $3+1^{*}$ & 2 & $3+2^{*}$ \\
\hline Fume hood & - & - & 2 & - & - & $1^{*}$ & 1 & - \\
\hline Stereomicroscope & - & 2 & - & - & 1 & - & - & - \\
\hline Dissecting microscope & 1 & - & - & 3 & 3 & - & 1 & - \\
\hline Tissue culture growth rooms & 2 & 1 & 7 & - & 3 & 2 & 1 & 1 \\
\hline \multicolumn{9}{|l|}{ Other accessories } \\
\hline Ice maker & - & - & 1 & - & - & - & - & - \\
\hline Indexing facility & - & - & - & - & 1 & - & - & - \\
\hline Screen house & 1 & 1 & - & - & 2 & - & 3 & 18 \\
\hline Bioreactor & $2+1^{*}$ & - & 25 & - & 1 & - & & - \\
\hline Shakers & 3 & $3+1^{*}$ & & & 2 & & 1 & \\
\hline Soil steam sterilizer & - & - & - & - & 1 & - & - & - \\
\hline
\end{tabular}

${ }^{*}$ Number of nonfunctional equipment in each institute; NABC: National Agricultural Biotechnology Research Center; MARC: Melkassa Agricultural Research Center; JARC: Jimma Agricultural Research Center; DZARC: Debre Zeit Agricultural Research Center; ARARI: Amhara Regional Agriculture Research Institute; ORARI: Oromia Regional Agriculture Research Institute; SARI: Southern Nations, Nationalities and People Region Agricultural Research Institute; TARI: Tigray Regional Agriculture Researcher Institute.

TABLE 2: List of basic equipment available in PTC laboratories at Ethiopian higher learning institutions.

\begin{tabular}{|c|c|c|c|c|c|c|c|}
\hline \multirow[t]{2}{*}{ Equipment } & \multicolumn{7}{|c|}{ Number of equipment in universities } \\
\hline & AAU & UoG & $\mathrm{HwU}$ & $\mathrm{HU}$ & JUCAVM & JUBD & WU \\
\hline \multicolumn{8}{|c|}{ Media preparation and autoclaving unit } \\
\hline Autoclaves & 1 & 1 & 1 & 3 & 1 & 1 & $3+1^{*}$ \\
\hline Precision balances & 1 & - & 1 & 1 & 1 & $1^{*}$ & $2+2^{*}$ \\
\hline $\mathrm{pH}$ meter & $1+2^{*}$ & 1 & 1 & 1 & 1 & - & $2+1^{*}$ \\
\hline Water purification apparatus & - & - & - & - & 1 & - & $2+4^{*}$ \\
\hline Refrigerated centrifuge & 1 & - & 1 & 1 & 2 & - & - \\
\hline Deep freezers $\left.\left(20^{\circ} \mathrm{C}\right)\right)$ & 1 & 1 & 1 & 1 & 2 & & 3 \\
\hline Fridge/freezer comb & 1 & 2 & 1 & 1 & 1 & - & 1 \\
\hline Hot plate with stirrer & $1+1^{*}$ & - & 4 & 3 & - & - & 3 \\
\hline Micropipettes (sets) & 2 & 3 & 1 & 8 & 1 & - & 5 \\
\hline Microwave oven & 1 & - & - & 1 & 2 & - & 3 \\
\hline Rotary shaker & $1+1^{*}$ & - & 1 & - & 1 & - & $5+1^{*}$ \\
\hline Water distiller (single) & 1 & 1 & - & 2 & $2^{*}$ & - & 3 \\
\hline Water distiller (double) & - & - & - & - & - & - & $1^{*}$ \\
\hline Deep freezer $\left(-80^{\circ} \mathrm{C}\right)$ & & & & & & & \\
\hline \multicolumn{8}{|c|}{ Working area and growth room unit } \\
\hline Laminar flow hood & $1+1$ & 2 & 2 & 2 & 1 & 1 & 2 \\
\hline Fume hood & - & - & - & 1 & - & - & 1 \\
\hline Stereomicroscope & - & - & - & - & 1 & - & - \\
\hline Dissecting microscope & - & $1^{*}$ & 1 & 1 & - & - & 1 \\
\hline
\end{tabular}


TABLE 2: Continued.

\begin{tabular}{|c|c|c|c|c|c|c|c|}
\hline \multirow[t]{2}{*}{ Equipment } & \multicolumn{7}{|c|}{ Number of equipment in universities } \\
\hline & AAU & UoG & $\mathrm{HwU}$ & $\mathrm{HU}$ & JUCAVM & JUBD & WU \\
\hline Tissue culture growth rooms & 1 & 2 & 1 & 1 & 1 & 1 & 2 \\
\hline \multicolumn{8}{|l|}{ Other accessories } \\
\hline Ice maker & - & - & - & - & - & - & 1 \\
\hline Indexing facility & - & - & - & - & - & - & - \\
\hline Screen house & - & - & - & - & 1 & - & - \\
\hline Bioreactor & - & - & - & - & - & - & - \\
\hline Shakers & $1+1^{*}$ & - & 2 & - & - & - & 3 \\
\hline Soil steam sterilizer & - & - & - & - & - & - & - \\
\hline
\end{tabular}

*Number of nonfunctional equipment in each institute; AAU: Addis Ababa University; UoG: University of Gonder; HwU: Hawassa University; HU: Haramaya University; JUCAVM: Jimma University College of Agriculture and Veterinary Medicine; JUBD: Jimma University Biology Department; WU: Wolkite University.

institutes (Table 2). However, the laboratory in this university lacks the proper design and structure to undertake tissue culture research, appropriate high-level experts, and a laboratory manager. On the other hand, Jimma University Biology Department has a very small and limited amount of basic PTC laboratory equipment (Table 2). Thus, there is a need to up-fit and equip the tissue culture laboratory with the required basic equipment. As compared to government research institutes, most of the laboratories in universities have limited tissue culture facilities and equipment. This may be since university laboratories are mainly used for educational purposes rather than for research. Nevertheless, besides education, these universities have the potential to contribute to the national effort of PTC research and development. Therefore, improving the laboratory infrastructure and capacity in these higher learning institutes requires critical attention for upgrading.

(3) Private Sector. The participation of the private sector in tissue culture activities in Ethiopia is expanding very rapidly. Currently, there are four (4) commercial plant TC laboratories in Ethiopia: Tigray Biotechnology Center (TBC), Dessie Tissue Culture Center, Bahir Dar Tissue Culture Enterprise, and Waginose Biotech. Among the commercial laboratories, TBC is well designed and equipped for tissue culture at each step of the process, followed by Dessie TC Center. This could be due to the fact that TBC was the first to be established and gained experience from subsequent expansion projects in scaling the production and distribution of TC plantlets. Consequently, TBC and Dessie TC Center are the top commercial TC labs with the highest production capacity of 40 million and 20 million plantlets per year, respectively (Table 3 ).

3.1.2. Plant Tissue Culture Expert. PTC laboratories need a strong technical base of field experts since culturing of plant cells, tissues, and organs is associated with the advancing of different knowledge like the biology of the plant cell, plant regulating hormones, analytical tools, and techniques [16]. Different categories of specialists are required at the various stages of the PTC process. The availability of an adequate amount of key professionals in PTC laboratories is one of the most important factors that affect the productivity of the lab. In this study, the human resource capacities of government and commercial tissue culture laboratories were assessed. The distribution of TC professionals across the studied institutes is not uniform (Figure 2). In terms of human capacity, the commercial labs have the highest share of laboratory technicians with an educational status of diploma and below diploma, followed by the regional research centers. On the other hand, the number of laboratory technicians and greenhouse technical assistants is limited in federal research centers and universities (Figure 2(a)). These institutes will need to increase the capacity of their technical staff so that they can fully exploit and benefit from tissue culture applications. Comparing the proportion of welltrained and skilled researchers within the assessed institutes, the number of Ph.D. professionals is higher in EIAR and universities (Figure 2(a)). This may be due to the need for highly qualified and experienced professionals for teaching and conducting high-impact research activities in universities and research centers.

Another important observation in this assessment is the gender composition of PTC professionals in both government-owned and commercial laboratories. The basic procedures of the PTC technique are very sensitive to contamination and should be implemented under very aseptic conditions. Therefore, certain attributes such as a focus on precision, hygiene, and strict adherence to each step of the procedure are key factors for a successful tissue culture implementation. Thus, the demanding nature of these laboratory tasks needs proper execution by people with dexterity and patience. It is well perceived by tissue culture industries that such responsibilities are performed well by women who possess nimble fingers [17]. In line with this, the numbers of women participants with the educational status of diploma and below diploma are higher than men in all assessed PTC laboratories. From this, it can be learned that there is a higher number of women laboratory technicians who conduct the most labor-intensive laboratory work. Moreover, the number of women at the higher levels with educational qualifications of MSc and Ph.D. degrees is very low (Figure 2(b)), resulting in a decreased number of women researchers and lab managers. Therefore, to achieve gender parity, there is a need to strengthen the participation and involvement of women at the higher technical and managerial levels rather than only restricting them to lower positions in the laboratories. 
TABLE 3: List of basic laboratories equipment available in commercial TC laboratories.

\begin{tabular}{|c|c|c|c|c|}
\hline \multirow[t]{2}{*}{ Equipment } & \multicolumn{4}{|c|}{ Number of equipment } \\
\hline & TBC (Mekelle) & Dessie TC Center & $\begin{array}{c}\text { Bahir Dar TC } \\
\text { Enterprise }\end{array}$ & Waginose Biotech \\
\hline \multicolumn{5}{|l|}{ Media preparation and autoclaving unit } \\
\hline Autoclaves & $4+8^{*}$ & 6 & $1+2^{*}$ & 1 \\
\hline Precision balances & $5+10^{*}$ & 3 & 2 & - \\
\hline $\mathrm{pH}$ meter & $1+4^{*}$ & $2+1^{*}$ & $2+4^{*}$ & 2 \\
\hline Water purification apparatus & 3 & 1 & - & 1 \\
\hline Refrigerated centrifuge & 1 & - & 2 & - \\
\hline Deep freezers $\left(-20^{\circ} \mathrm{C}\right)$ & 4 & - & - & 1 \\
\hline Fridge/freezer comb & - & - & - & - \\
\hline Hot plate with stirrer & - & 4 & 1 & - \\
\hline Micropipettes (sets) & 3 & - & - & 2 \\
\hline Microwave oven & 2 & - & 1 & - \\
\hline Rotary shaker & - & - & 1 & - \\
\hline Water distiller (single) & - & 1 & $1+2^{*}$ & 1 \\
\hline Water distiller (double) & 2 & 1 & - & - \\
\hline \multicolumn{5}{|l|}{ Working area and growth room } \\
\hline Laminar flow hood & $86+6^{*}$ & 5 & 2 & 2 \\
\hline Stereomicroscope & 1 & - & - & - \\
\hline Dissecting microscope & 1 & - & - & - \\
\hline Tissue culture growth rooms & 17 & 6 & 4 & 1 \\
\hline \multicolumn{5}{|l|}{ Other accessories } \\
\hline Ice maker & - & - & - & - \\
\hline Indexing facility & - & - & - & - \\
\hline Screen house & - & - & - & - \\
\hline Bioreactor & - & - & - & - \\
\hline Shakers & $1^{*}$ & - & 1 & - \\
\hline Greenhouse & 15 & 9 & - & - \\
\hline Production capacity (plantlets per year) & $40,000,000$ & $20,000,000$ & $5,000,000$ & \\
\hline
\end{tabular}

${ }^{*}$ Number of nonfunctional equipment in each institute; TBC: Tigray Biotechnology Center.

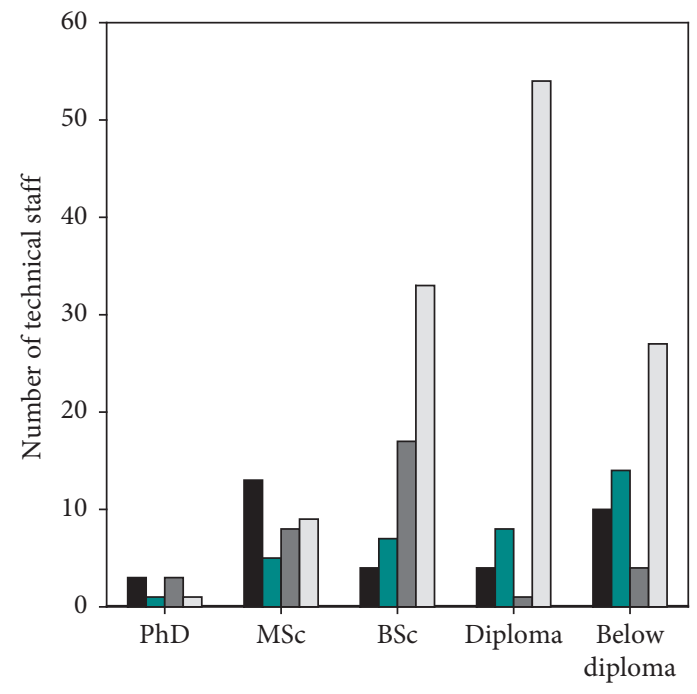

Education level

EIAR

RARIs

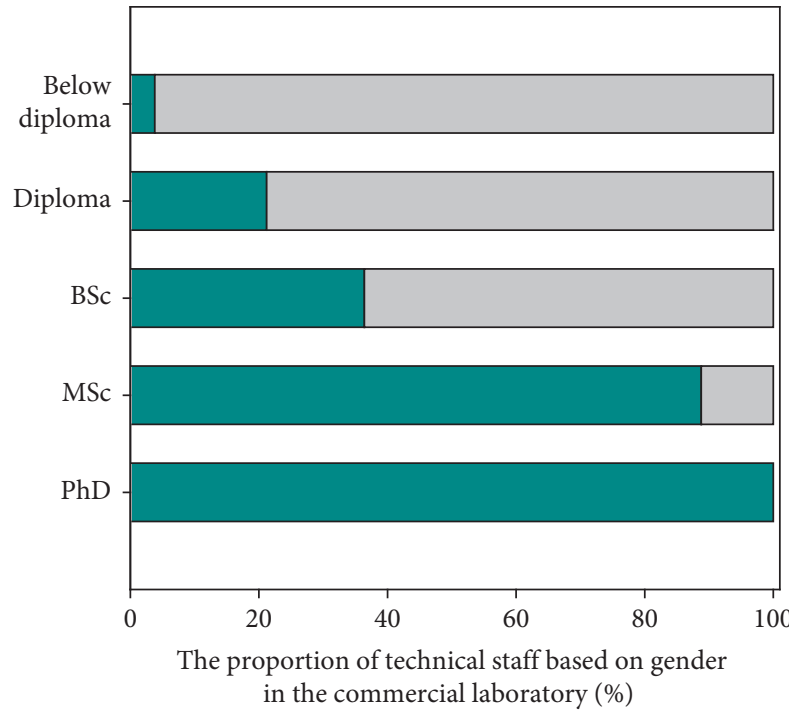

$\square$ Male

$\square$ Female

(a)

(b)

FIgUre 2: Status and distribution of PTC technical staff in different laboratories. (a) The number of technical staff in currently active PTC laboratory based on education status. (b) Gender proportion of plant TC technical staff in commercial laboratories. 
3.1.3. Progress of PTC Protocols. PTC depends on the ability of plant tissue to give rise to an entirely new plant when provided with a growth medium and appropriate environment [16]. Thus, in vitro PTC procedures have been standardized for each plant species and series of important applications [18]. Therefore, assessments have been made to identify plant species with tissue culture protocols in optimization in Ethiopian tissue culture laboratories, along with the purpose of each protocol.

(1) Plants Tissue Culture Protocols. The study revealed that a total of fifty-four (54) plant species have been under in vitro protocol optimization/development process across all assessed PTC laboratories (Supplementary file 3). For simplification, these plant species have been grouped into eight (8) different categories, which are root and tuber, fruits, commercial crops, medicinal plants and spices, vegetables, oil crops, trees, and cereals. Among these categories, the medicinal plants and spices group contain a higher number of plant species that are in the pipeline for tissue culture protocol optimization/development process (Figure 3(a)). This might be due to the availability of diverse flora compositions of medicinal plants and spices in Ethiopia $[19,20]$.

PTC techniques are crucial for mass propagation, production of disease-free and genetically homogeneous plants, and rapid multiplication of rare plant genotypes, plant genome transformation, and production of secondary metabolites [10, 21]. Besides, it is used for the production of haploids [22], conserving rare and endangered plant species $[23,24]$. The results of this assessment showed that the purpose of current TC protocols developed in Ethiopia was for mass propagation (66\%), disease-free planting material production (15\%), conservation (9\%), and haploid production (8\%) (Figure 3(b)). Accordingly, all developed protocols in the tree plants category have been developed for mass propagation. Whereas for plant species in the commercial, medicinal and vegetable categories, tissue culture protocols were optimized for mass propagation and virus/ bacteria cleaning. Furthermore, for plant species in fruits, root, and tuber categories, tissue culture protocols were optimized for the mixed purpose of mass propagation, conservation, and virus/bacteria cleaning. This is possible because mass propagation, producing disease-free planting material and conservation are the most widely applied tissue culture technique and have a direct impact on commercial production in horticultural crops $[25,26]$.

Tissue culture optimization protocol for regeneration purposes was undertaken only for oil crops. Interestingly, in the cereal crop category, tissue culture protocol was developed only for haploid production (Figure 3(c)). In this case, wheat and tef crops were the main focus crops for haploid and embryo regeneration protocol development and optimization [27, 28]. Haploids and embryo regeneration is an effective technique that is employed to shorten the breeding cycle of plants $[22,29]$. It is also well documented that the application of in vitro haploid culture in most selfpollinated species like cereals is mainly to accelerate crop improvement programs [30,31]. Therefore, the purpose of PTC protocol in cereal and oil crops categories that was witnessed in this study may be due to its target on facilitating breeding procedures using in vitro haploid cultures and embryo regeneration techniques.

(2) Plants with Well-Established TC Protocol. Over the past year, most PTC research emphasized protocol optimization for micropropagation and virus elimination in economically and industrially important plant species including banana, grapevine, citrus, potato, enset, coffee, pineapple, hot pepper, sweet potato, cassava, and so on [32]. Distribution of a large number of tissue culture plants like sugar cane, banana, cassava, hybrid coffee, sweet potato, pineapple, and potato to farmers in various parts of the country are major achievements of PTC research and development in Ethiopia [33]. In the present assessment, PTC protocol optimization/development for plant species being implemented in all the assessed PTC laboratories is presented in Supplementary file 3. Among the plant species that have completed PTC protocols, seventeen (17) plant species have been commonly practiced in more than two (2) PTC laboratories (Table 4). Accordingly, some of the horticultural plants like potato (Solanum tuberosum L.), sweet potato (Ipomoea batatas), banana (Musa spp), pineapple (Ananas comosus), and sugarcane (Saccharum officinarum) have a well-established TC protocol for large-scale production in Ethiopia. These tissue culture protocols have been properly implemented in most of the assessed laboratories. This might be due to the high economic and social importance of the crops and the significant contributions of PTC technology on propagation and crop improvement programs. For instance, rapid multiplication of disease-free planting material through micropropagation technology has been a primary step towards quality seed production of potato and minimizes the effect of viruses on potato yield in Ethiopia [34]. In addition, due to the need for the production of sugar at the export level and the expansion of huge sugar industries across the country, large-scale production of disease-free and quality planting material of sugarcane has been achieved through PTC technology in Ethiopia [35].

The status of each protocol optimization/development process for all eight (8) groups of plant species are categorized as ongoing, completed, and scaled up. The PTC protocol optimization/development grouped under ongoing status is those that have started and documented most of the protocol steps for the in vitro technique. Those that are grouped in the completed status have finalized all the steps of the protocol optimization/development process at the research level. Protocols that have been successfully transferred and implemented at a large scale were categorized under scaled-up status. The assessment revealed that among the total plant species that are under tissue culture protocol optimization/development process, twenty (20) species are under ongoing status (Figure 3(a)). On the other hand, there are about thirty-three (33) plant species that have completed optimized/developed tissue culture protocols. Among the completed protocols, only six (6) protocols optimization for potato, sweet potato, banana, pineapple, sugarcane, and ginger have been scaled up 


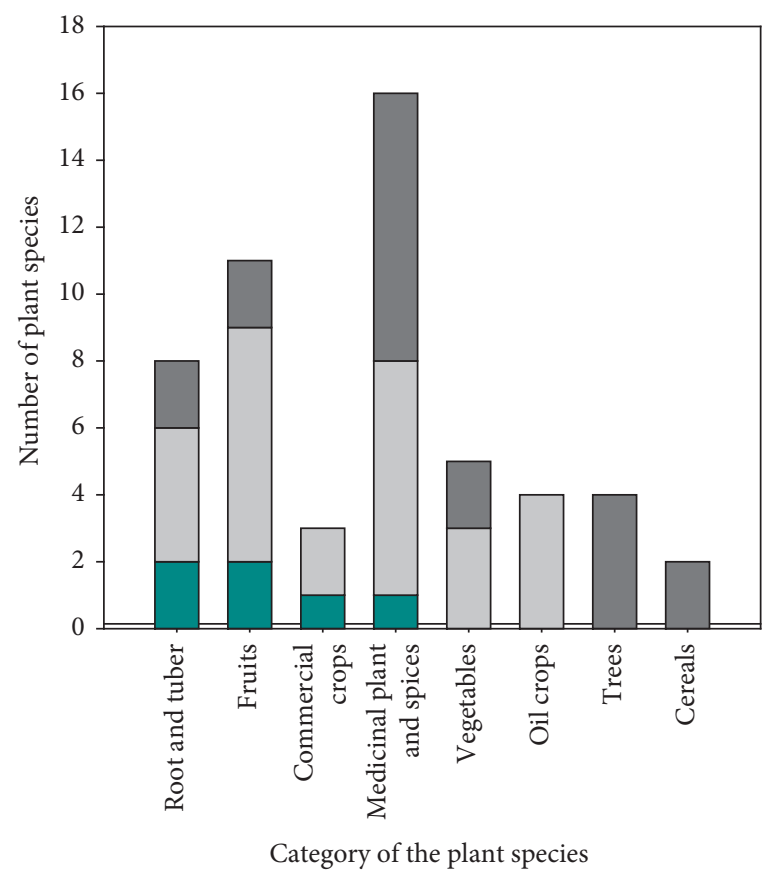

Status of the protocol

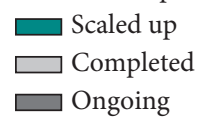

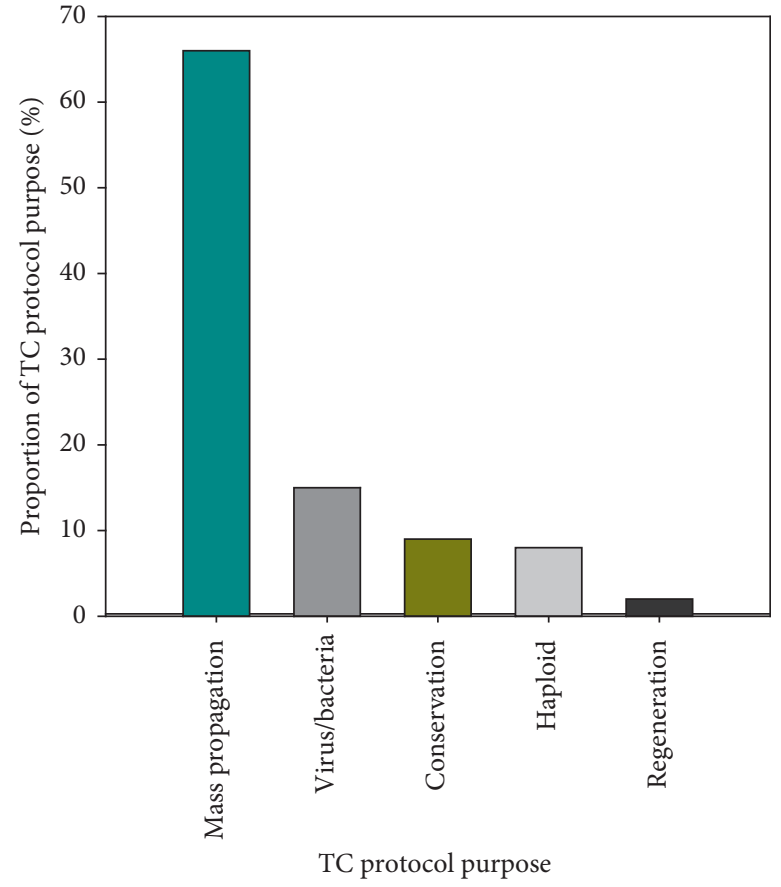

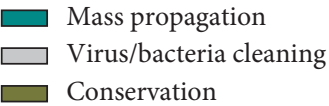

(b)

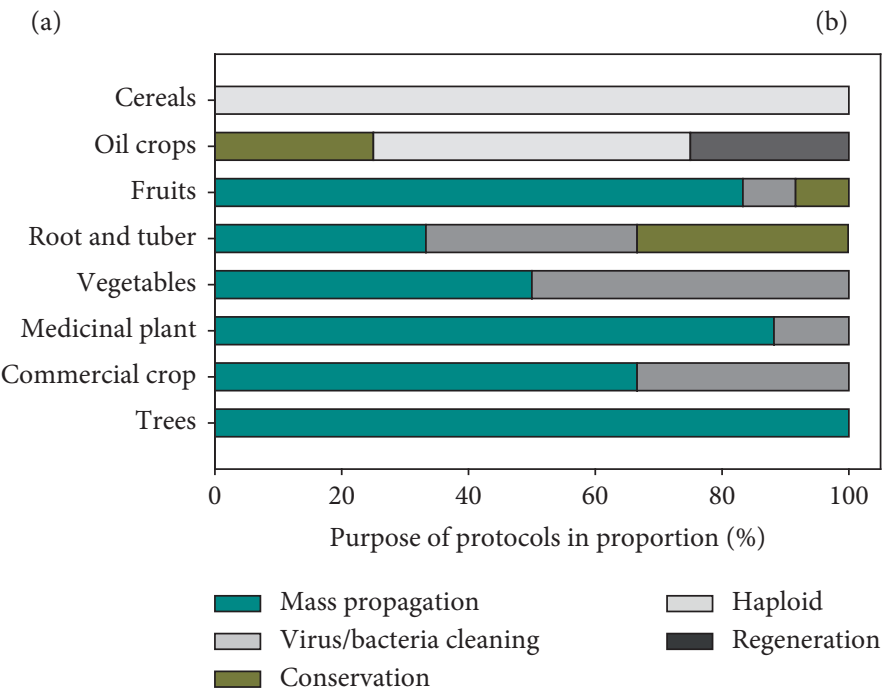

(c)

FIgURE 3: Status and purpose of plant tissue culture protocol developed and/or optimized in Ethiopian TC laboratories. (a) The number of plant species that have been under TC protocol optimization/development process, (b) proportion of the purpose of PTC protocols optimized/developed in the assessed laboratories, and (c) proportion of the purpose of PTC protocol in each plant category.

at a large scale (Table 4). The scaling-up process of PTC protocols in Ethiopian research and development is very limited. In line with this, the uptake and impact of innovations have been limited and many agricultural technologies in Sub-Saharan Africa remain “on the shelf” [36]. Farmer' access to extension services like training, demonstration, field day has a critical influence to promote technology adoption in developing countries [37].
Therefore, the low uptake of PTC technology in Ethiopia might be due to the limited access to extension services in the sector. In addition, the innovative technologies are not well-matched with the producers' capabilities and local economic status $[38,40]$. Therefore, further interventions like creating a conducive research environment and investment incentive packages are critical to improving the scale-up rate of protocols in the Ethiopian PTC sector. 
TABLE 4: List of plant species that have completed PTC protocol and practices in more than two laboratories.

\begin{tabular}{|c|c|c|c|c|}
\hline Plant category & $\begin{array}{l}\text { Common and botanical } \\
\text { name }\end{array}$ & $\begin{array}{l}\text { The main purpose of the } \\
\text { protocol }\end{array}$ & $\begin{array}{l}\text { Statues of the } \\
\text { protocol } \\
\text { 1-scaled up } \\
\text { 2-completed }\end{array}$ & Engaged institutes \\
\hline \multirow{6}{*}{ Root and tuber } & $\begin{array}{l}\text { Potato (Solanum } \\
\text { tuberosum L.) }\end{array}$ & $\begin{array}{l}\text { Mass propagation, virus } \\
\text { cleaning conservation }\end{array}$ & 1 & $\begin{array}{l}\text { ARARI, NABRC, ORARI, TARI, } \\
\text { HwU, Dessie TC, TBC, JUCAVM }\end{array}$ \\
\hline & $\begin{array}{c}\text { Sweet potato (Ipomoea } \\
\text { batatas) }\end{array}$ & $\begin{array}{l}\text { Mass propagation, virus } \\
\text { cleaning conservation }\end{array}$ & 1 & $\begin{array}{c}\text { NABRC/ARARI, ORARI, SARI, HwU, } \\
\text { TBC, AAU }\end{array}$ \\
\hline & $\begin{array}{l}\text { Enset (Ensete } \\
\text { ventricosum) }\end{array}$ & Mass propagation & 2 & NABRC, SARI, HwU, WU, TBC, AAU \\
\hline & $\begin{array}{l}\text { Cassava (Manihot } \\
\text { esculenta) }\end{array}$ & Virus cleaning & 2 & NABRC, AAU \\
\hline & $\begin{array}{l}\text { Anchote (Coccinia } \\
\text { abyssinica) }\end{array}$ & Virus cleaning & 2 & NABRC, DARC \\
\hline & Yam (Dioscorea $s p p)$ & Mass propagation & 2 & JARC, SARI, HwU \\
\hline \multirow{5}{*}{ Fruits } & Banana (Musa spp) & Mass propagation & 1 & $\begin{array}{c}\text { MARC, ARARI, ORARI, SARI, Dessie } \\
\text { TC, JUCAVM, TBC, }\end{array}$ \\
\hline & $\begin{array}{l}\text { Pineapple (Ananas } \\
\text { comosus) }\end{array}$ & Mass propagation & 1 & SARI, JARC, TBC, Waginose Biotech \\
\hline & Apple (Malus domestica) & Mass propagation & 2 & $\begin{array}{c}\text { NABRC, WKU, JUCAVM, Bahir Dar } \\
\text { TC Enterprise, TBC, AAU }\end{array}$ \\
\hline & Grape (Vitis vinifera) & Mass propagation & 2 & NBAC, DARC, TBC, AAU \\
\hline & Citrus (Citrus spp) & Virus/bacteria cleaning & 2 & JUCAVM, TBC \\
\hline \multirow{2}{*}{ Commercial crops } & $\begin{array}{l}\text { Coffee (Coffea arabica } \\
\text { L.) }\end{array}$ & Mass propagation & 2 & $\begin{array}{c}\text { NABRC, JARC, DARC, ORARI, AAU, } \\
\text { TBC }\end{array}$ \\
\hline & $\begin{array}{c}\text { Sugar cane (Saccharum } \\
\text { officinarum) }\end{array}$ & Mass propagation & 1 & $\begin{array}{c}\text { NABRC, MARC, JUCAVM, AAU, } \\
\text { TBC, Waginose Biotech }\end{array}$ \\
\hline Oil crops & $\begin{array}{l}\text { Ethiopian mustard } \\
\text { (Brassica carinata) }\end{array}$ & $\begin{array}{l}\text { Regeneration, haploid } \\
\text { production }\end{array}$ & 2 & NABRC, AAU \\
\hline \multirow{3}{*}{$\begin{array}{l}\text { Medicinal plants } \\
\text { and spices }\end{array}$} & $\begin{array}{l}\text { Ginger (Zingiber } \\
\text { officinalis) }\end{array}$ & $\begin{array}{l}\text { Mass propagation, virus } \\
\text { cleaning conservation }\end{array}$ & 1 & SARI, ARARI, UoG, JARC, TBC, AAU \\
\hline & $\begin{array}{l}\text { Endod (Phytolacca } \\
\text { dodecandra) }\end{array}$ & Mass propagation & 2 & JARC, TBC \\
\hline & Garlic (Allium sativum) & Virus cleaning & 2 & DARC, JUCAVM \\
\hline
\end{tabular}

Note: NABRC: National Agricultural Biotechnology Research Center; MARC: Melkassa Agricultural Research Center; JARC: Jimma Agricultural Research Center; DZARC: Debre Zeit Agricultural Research Center; ARARI: Amhara Regional Agriculture Research Institute; ORARI: Oromia Regional Agriculture Research Institute; SARI: Southern Nations, Nationalities and People Region Agricultural Research Institute; TARI: Tigray Regional Agriculture Researcher Institute. AAU: Addis Ababa University; UoG: University of Gonder; HwU: Hawassa University; JUCAVM: Jimma University College of Agriculture and Veterinary Medicine; WU: Wolkite University.

3.2. Challenges of PTC Research and Development. Tissue culture application in public and private sectors in Ethiopia is limited by several technical, administrative, and financial constraints. To realize the potential of tissue culture in uplifting agricultural productivity in Ethiopia, developing solutions to these constraints is a necessity. Undoubtedly, intervention measures to address these issues will require an interplay of several individuals and institutions that should be supported by appropriate national and regional governments. In this study, several challenges associated with tissue culture R\&D within the assessed nineteen (19) tissue culture laboratories were identified and presented below. Most of the identified challenges appear to be similar across all institutes. A summary of the key constraints and gaps identified in this assessment is listed as follows:

(i) Lack of an adequate number of well-trained and experienced tissue culture personnel: in most of the assessed laboratories, lack of skilled PTC expertise and high staff turnover was the major challenge.
Furthermore, an available engineer and/or qualified technician for maintenance and repair of tissue culture equipment and overall facility maintenance were critically limited for all the assessed laboratories.

(ii) Lack of appropriate tissue culture infrastructure: in government-owned laboratories, the lack of appropriate tissue culture infrastructure was a serious bottleneck. This was exacerbated by unreliable utility services (electrical power and water supply). Additionally, low efficiencies at various steps in the TC process resulted in very low productivity due to the multiplicative effect of low Rolled Throughput Yield (RTY).

(iii) Shortage of budget and financial support: inadequate funding by the federal and regional governments for tissue culture laboratory work. Moreover, an overly bureaucratic government procurement directive and procedures system is also identified as 
an obstacle for tissue culture supply system efficient operation, particularly for the purchase of consumables.

(iv) Poor investment incentives: inadequate national and/or regional policy frameworks to support private sector involvement in PTC.

(v) Production cost: relatively high unit cost of tissue culture products compared to their conventional counterparts.

(vi) Poor linkages and limited awareness: weak collaborative linkages and/or partnerships among the different stakeholders along the tissue culture development and delivery pipeline have been a challenge for biotechnology $\mathrm{R} \& \mathrm{D}$ in general and tissue culture in particular. Limited public awareness about proven tissue culture products and technologies was also identified as a key challenge.

Based on the assessment results, the challenges were ranked according to the intensity of the challenge in each institute (Research Institutes, Universities, and Commercial Labs). In Research Institutes, laboratory equipment maintenance got the highest rank, followed by procurement procedure and limited awareness about proven tissue culture products. In Universities, procurement procedure scored a higher rank, followed by the accessibility of chemicals/reagents in local market and laboratory equipment maintenance, whereas in Commercial Labs, limited awareness about proven tissue culture products was found to be highly challenging, followed by weak collaborative linkages and/or partnership among the different stakeholders along with the tissue culture development and delivery pipeline and laboratory equipment maintenance.

Both in research institutes and universities, procurement procedures were found to be the second most challenging factor in tissue culture R\&D. This might be because both institutions are governmental organizations and are regulated by public procurement procedures. In Ethiopia, from the total public expenditure, more than $60 \%$ is used for the procurement of goods and services [40]. However, the public procurement regimes in Ethiopia reveal a lot of shortcomings such as procurement laws and regulations that are not based on recognized international models, absence of clearly defined central oversight and public bodies at all levels, shortage of experienced management and procurement staff, lack of transparency in the procurement processes, and absence of procedures for a modern form of procurement activities and unclear institutional and organizational arrangement required in the management of the public procurement process [41].

Laboratory equipment maintenance problem was mentioned in all assessed institutes. This might be due to three factors: (a) absence of proper maintenance documentation, (b) no local suppliers for spares, and (c) inadequate expertise. The absence of critical spare parts on hand, combined with no local supplier and the importation of spares, usually leads to prolonged lead times and delays in timely repairs to malfunctioning critical equipment and thus early obsolescence. Therefore, improving the public procurement system will have a substantial impact on the growing economy of Ethiopia, which will result in budgetary savings and efficiencies in government expenditures, thereby creating wealth and reducing poverty.

\subsection{Plant Tissue Culture Industry Prospects in Ethiopia.} The following three factors underlie the current prospects for the PTC industry in Ethiopia:

(1) Demand for agricultural productivity improvement: African agriculture has enormous potential, not only to feed itself, eliminate hunger and food insecurity but also to be a major player in global food markets. As a sector, it can therefore contribute towards major national and continental priorities, such as eradicating poverty and hunger, boosting intra-Africa trade and investments, increase input for industry and economic diversification, sustainable resource and environmental management, and creating jobs and shared prosperity. Seizing these opportunities will require African agriculture to become more modern, profitable, demand-driven, and businessoriented. In this regard, PTC technology is a key enabler for the African agricultural system to significantly improve plant productivity. Similarly, in the Ethiopian agricultural system, tissue culture can create several opportunities to transform some economic sectors, including sugarcane, hybrid coffee, and horticulture, as well as food crops with a focus on root and tubers.

(2) Availability of laboratory facilities and labor: the application of PTC technology is one of the most commercially successful tools in horticultural plant propagation. It has offered new opportunities to many companies in Europe and the US during the 1980s. Currently, this industry appears to be undergoing a pause in developed countries as it is finding it difficult to remain cost-effective due to high labor costs. Global plant tissue culture companies have been a model experience in outsourcing production orders with developing countries like India [42]. Outsourcing is an attractive option for industries from developed countries since PTC is a labor-intensive technology and labor represents a significant proportion of the total production cost. In addition to lower labor costs, Ethiopia has a good head start on establishing commercial PTC. It already has two (2) international-standard commercial laboratories at Tigray Biotechnology Center and Dessie Tissue Culture Center, with an annual production capacity of 40 million and 20 million plantlets, respectively. These commercial enterprises can be the outsourcing centers for global and regional tissue culture industries.

(3) Availability of new technologies: currently, there are hybrid and improved varieties for several horticultural crops. Most of these varieties need PTC to 
multiply and distribute to the farmers. Furthermore, the availability of biotechnology tools like transgenic and gene editing to develop pests, diseases, and abiotic stresses tolerant crops also need the intervention of PTC. These achievements of technologies may predict the potential victory of the PTC industry in Ethiopia.

\section{Conclusion}

In general, PTC R\&D in Ethiopia has made significant progress. The advantage of tissue culture for rapid and largescale multiplication of plants has been widely recognized in the country and research efforts are now being extended to different research institutes such as national agricultural research institutes, regional agricultural research institutes, and higher learning institutes. These government institutes have recently developed their capacity and initiated tissue culture work for micropropagation of selected crops of importance in their respective geographical area. Moreover, private enterprises like Tigray Biotechnology Center, Dessie Tissue Culture, Bahir Dar Tissue Culture Enterprise, and Waginos Biotech have been engaged in large-scale multiplication and propagation of tissue culture of crops including potato, banana, sugarcane, sweet potato, and ginger. Despite this progress, the tissue culture sector in Ethiopia is limited by several technical, administrative, and financial constraints.

In summary, plant tissue culture technology is one of the likely opportunities for Ethiopia's agricultural system to enhance crop productivity. Although not a sole solution to the many challenges faced in Ethiopian crop production, tissue culture can be a significant component of the approach to improve the quality and productivity of economically important crops of the country. This requires appropriate $\mathrm{R} \& \mathrm{D}$ strategies to solve major challenges in the sector.

\section{Data Availability}

Data are available upon request. Some data are available as a supplementary document.

\section{Disclosure}

Dagmawit Chombe Tobiaw, Birhan Addisie Abate, Beza Kinfe Eshete, Sydney K. Seymour, and Kassahun Tesfaye are the co-authors.

\section{Conflicts of Interest}

The authors declare no conflicts of interest.

\section{Authors' Contributions}

Y.A, D.T, B.A, and B.K designed and conducted the assessment, analyzed the data, and co-wrote the paper. K.T provided a general guidance for all aspects of the assessment and co-wrote the paper. S.S contributed in the preparation of the questionnaire and co-wrote the paper.

\section{Supplementary Materials}

Supplementary file 1: Questionnaire for the assessment of status, potential, and challenges of tissue culture research and development in Ethiopia. The questionnaire has five sections. Supplementary file 2: identified laboratory facility structure and design bottlenecks in different laboratory compartments across all assessed laboratories. Supplementary file 3: list of plant species that have been under PTC protocols development for important crops in Ethiopia. The study revealed that a total of fifty-four (54) plant species have been under in vitro protocol optimization/development process across all assessed PTC laboratories. The list of these all plant species is presented in Supplementary file 3. (Supplementary Materials)

\section{References}

[1] K. H. Neumann, A. Kumar, and J. Imani, Plant Cell and Tissue Culture-A Tool in Biotechnology: Basics and Application, Springer Science \& Business Media, Heidelberg, Germany, 2009.

[2] F. Skoog and C. O. Miller, "Chemical regulation of growth and organformation in plant tissue cultures in vitro," Symposia of the Society for Experimental Biology, vol. 11, pp. 118-131, 1957.

[3] A. Komamine, R. Kawahara, M. Matsumoto et al., "Mechanisms of somatic embryogenesis in cell cultures: physiology, biochemistry, and molecular biology," Vitro Cellular \& Developmental Biology-Plant, vol. 28, no. 1, pp. 11-14, 1992.

[4] G. Morel, "Producing virus-free cymbidium," American Orchid Society Bulletin, vol. 29, pp. 495-497, 1960.

[5] S. Guha and S. C. Maheshwari, "In vitro production of embryos from anthers of Datura," Nature, vol. 204, p. 497, 1964.

[6] B. Kaul and E. J. Staba, "Visnagin: biosynthesis and isolation from Ammi visnagi suspension cultures," Science, vol. 150, no. 3704, pp. 1731-1732, 1965.

[7] M. Noguchi, T. Matsumoto, Y Hirata et al., "Improvement of growth rates of plant cell cultures," in Plant Tissue Culture and its Bio-Technological Application, pp. 85-94, Springer, Berlin, Germany, 1977.

[8] D. C. Brown and T. A. Thorpe, "Crop improvement through tissue culture," World Journal of Microbiology and Biotechnology, vol. 11, no. 4, pp. 409-415, 1995.

[9] M. A. Hinchee, D. R. Corbin, C. L. Armstrong et al., "Plant transformation," in Plant Cell and Tissue Culture, pp. 231270, Springer, Dordrecht, The Netherlands, 1994.

[10] F. Altpeter, N. M. Springer, L. E. Bartley et al., "Advancing crop transformation in the era of genome editing," The Plant Cell, vol. 28, no. 7, pp. 1510-1520, 2016.

[11] P. S. Srivastava, M. Iqbal, and M. H. Mughal, "Role of tissue culture in plant disease control," in Biotechnological Approaches in Biocontrol of Plant Pathogens, pp. 197-217, Springer, Boston, MA, USA, 1999.

[12] K. Yoshimatsu, "Tissue culture of medicinal plants: micropropagation, transformation and production of useful secondary metabolites," Studies in Natural Products Chemistry, vol. 34, pp. 647-752, 2008.

[13] A. S. Mohammed, "Plant tissue culture biotechnology in Ethiopia: challenges and opportunities," Research \& Reviews in Bio-Sciences, vol. 7, no. 7, pp. 249-255, 2013.

[14] R. Kumar, Laboratory Requirements in Plant Tissue Culture, Institute of Lifelong Learning, University of Delhi, Delhi, India, 2015. 
[15] C. W. Masiga, E. Mneney, F. Wachira, and C. Mugoya, Situational Analysis of the Current State of Tissue Culture Application in the Eastern and Central Africa Region, Association for Strengthening Agricultural Research in East and Central Africa (ASARECA), Entebbe, Uganda, 2013.

[16] T. A. Thorpe, "History of plant tissue culture," Molecular Biotechnology, vol. 37, pp. 169-180, 2007.

[17] C. R. Reddy, "Plant tissue culture industry and women's participation: "nimble fingers" or docile labor," Gender, Technology and Development, vol. 11, no. 2, pp. 179-198, 2007.

[18] V. M. Loyola-Vargas and N. Ochoa-Alejo, "An introduction to plant cell culture: the future ahead," in Plant Cell Culture Protocols, pp. 1-8, Humana Press, Totowa, NJ, USA, 2012.

[19] T. Birhanu, D. Abera, E. Ejeta, and E. Nekemte, "Ethnobotanical study of medicinal plants in selected horro gudurru woredas, western Ethiopia," Journal of Biology, Agriculture and Healthcare, vol. 5, no. 1, pp. 83-93, 2015.

[20] CBD Convention on Biological Diversity, Forest and Aquatic Plants Genetic Resources, Institute of Biodiversity Conservation, Addis Ababa, Ethiopia, 2008.

[21] T. R. Sinclair, L. C. Purcell, and C. H. Sneller, "Crop transformation and the challenge to increase yield potential," Trends in Plant Science, vol. 9, pp. 70-75, 2004.

[22] R. A. Morrison and D. A. Evans, "Haploid plants from tissue culture: new plant varieties in a shortened time frame," Nature Biotechnology, vol. 6, pp. 684-690, 1998.

[23] A. R. Filho, L. L. Dal Vesco, R. O. Nodari, R. W. Lischka, C. V. Müller, and M. P. Guerra, "Tissue culture for the conservation and mass propagation of Vriesea reitzii Leme and Costa, abromelian threatened of extinction from the Brazilian Atlantic Forest," Biodiversity and Conservation, vol. 14, no. 8, pp. 1799-1808, 2005.

[24] R. K. Tyagi, A. Agrawal, C. Mahalakshmi, Z. Hussain, and H. Tyagi, "Low-cost media for in vitro conservation of turmeric (Curcuma longa L.) and genetic stability assessment using RAPD markers," In Vitro Cellular \& Developmental Biology-Plant.vol. 43, pp. 51-58, 2007.

[25] K. C. Torres, Tissue Culture Techniques for Horticultural Crops, Springer Science \& Business Media, Berlin, Germany, 2012.

[26] A. Shahzad, S. Parveen, S. Sharma et al., "Plant tissue culture: applications in plant improvement and conservation," in Plant Biotechnology: Principles and Applications, pp. 37-72, Springer, Singapore, 2017.

[27] T. Getahun, T. Feyissa, and L. Gugsa, "Regeneration of plantlets from unpollinated ovary cultures of Ethiopian wheat (Triticum turgidum and Triticum aestivum)," African Journal of Biotechnology, vol. 12, no. 39, 2013.

[28] L. Gugsa and J. Kumlehn, "Haploidy in tef," in Advances in Haploid Production in Higher Plants, pp. 265-284, Springer, Dordrecht, The Netherlands, 2009.

[29] M. Liotino, A. Varangot, A. Beznec et al., "Shortening of generation cycles in inbred lines of maize (Zea mays L.) through embryo rescue technique," Istituto Sperimentale per la Cerealicoltura, vol. 64, no. 2, 2019.

[30] W. B. Thomas, B. P. Forster, and B. Gertsson, "Doubled haploids in breeding," in Doubled Haploid Production in Crop Plants: A Manual, M. Maluszynski, K. J. Kasha, B. P. Forster, and I. Szarejko, Eds., Kluwer, Dordrecht, The Netherlands, pp. 337-349, 2003.

[31] R. Mishra and G. J. Rao, "In-vitro an drogenesis in rice: advantages, constraints and future prospects," Rice Science, vol. 23, no. 2, pp. 57-68, 2016.
[32] EIAR (Ethiopian Institute of Agricultural Research), Agricultural Biotechnology Research Activities and Achievement, EIAR (Ethiopian Institute of Agricultural Research), Holetta, Ethiopia, 2016.

[33] B. Lemaga, R. Kakuhenzire, P. Gildemacher, D. Borus, and W. G. Gebremedhin, "Current status and opportunities for improving the access to quality potato seed by small farmers in Eastern Africa," in Proceeedings of the Symposium 15th Triennial of the Symposium of the International Society for Tropical Root Crops, pp. 2-6, Lima, Peru, 2009.

[34] H. Tegen and W. Mohammed, "The role of plant tissue culture to supply disease free planting materials of major horticultural crops in Ethiopia," Journal of Biology, Agriculture and Healthcare, vol. 6, no. 1, pp. 122-129, 2016.

[35] B. Tolera, M. Diro, and D. Belew, "In vitro aseptic culture establishment of sugarcane (Saccharum officinarum L.) varieties using shoot tip explants," Advances in Crop Science and Technology, vol. 2, no. 3, pp. 1-6, 2014.

[36] M. T. Ajayi, A. O. Fatunbi, and O. O. Akinbamijo, Strategies for Scaling Agricultural Technologies in Africa, Accra: Forum for Agricultural Research in Africa (FARA), Accra, Ghana, 2018.

[37] B. Melesse, "A review on factors affecting adoption of agricultural new technologies in Ethiopia," Journal of Agricultural Science and Food Research, vol. 9, no. 3, pp. 1-4, 2018.

[38] E. Rogers, Diffusion of Innovations, McMillan, New York, NY, USA, 3rd edition, 2003.

[39] D. Glover, J. P. Venot, and H. Maat, "On the movement of agricultural technologies packaging, unpacking and situated reconfiguration," in Agronomy for Development: The Politics of Knowledge in Agricultural Research, J. Sumberg, Ed., pp. 14-30, Routledge, Abingdon, UK, 2017.

[40] Y. Tesfahun, Public Procurement Reforms in Ethiopia: Policy and Institutional Challenges and Prospects, p. 1267, Addis Ababa University, Addis Ababa, Ethiopia, 2011.

[41] Getnet Amdework Chekol, "Public procurement reform in Ethiopia: factors leading to effective public procurement implementation: the case of Amhara region," European Journal of Business and Management, vol. 6, no. 23, pp. 2222-2839, 2014.

[42] S. Prakash, "Role of women in biotechnology and rural development," in Biotechnology and Sustainable Development NISIET, Hyderabad, Telangana, 2001. 